\title{
Ssciendo
}

DOI 10.2478/afepuc-2021-0015

(C) 2021 Author(s). This is an open access article licensed under the Creative Commons

Attribution-NonCommercial-NoDerivatives 4.0 International

(https://creativecommons.org/licenses/by-nc-nd/4.0/)

\section{ROLE OF FITNESS PROGRAM IN A HEALTH IMPROVEMENT OF ADOLESCENTS}

\section{Gorana Tesanovic, Goran Bosnjak, Vladimir Jakovljevic, Radomir Zrnic \\ Faculty of Physical Education and Sport, University of Banja Luka, Bosnia and Herzegovina}

Summary: Since physical activities affect the quality of life and activate a complete locomotor system, sports and physical activities can be treated as a determinant for a harmonious development of all child's characteristics and anthropological characteristics. Because, childhood and youth are the most important formative periods, and some segments of development, for example, specific motor skills can be developed only with means used in sports, this research was conducted to find out do the fitness program (aimed at improving strength) after eight weeks had a positive effect on body composition and mobility and stability of subjects. A control group consisted of 11 female subjects and experimental group were 11 female subjects aged 16 years. The effects of the program on the fitness condition of the subjects were determined by assessing the body composition parameters (data obtained using the Body composition analyser TANITA BC-418) the total percentage of fat tissue (FAT), the percentage of fat tissue segmentally (percentage of fat tissue of the left leg (FATll), right leg (FATrl), left arm (FATla), right arm (FATra) and body (FATb)) and estimation of mobility and stability levels - based on the application of Functional movement screening (FMS) method (seven tests) before and after the program is implemented. The success of the implemented program was confirmed because the program showed a statistically significant difference between the mobility groups of the subjects in the experimental in relation to the control group (deep squat $t=3,464 \mathrm{p}=0,006$, step over a hurdle $\mathrm{t}=2,390 \mathrm{p}=0,038$, active lift of a stretched leg $\mathrm{t}=2,887 \mathrm{p}=0,016$, rotatory body stability $\mathrm{t}=3,130 \mathrm{p}=0,011$ and FMS $t=5,721 \mathrm{p}=0,000$ ), and a positive effect on the composition of the body in terms of reduction of the percentage of fatty body has been shown segmentally.

Keywords: fitness program, adolescents, body composition, FMS method 


\section{Introduction}

Regular physical activity is very important for both men and women's health (US Department of Health and Human Services 1996), witha a recommendation that adults and elderly people should actively participate in all aspects of physical activity of moderate intensity for at least 30 minutes daily in order to maintain mobility (WHO 2010). Doing some sports, whether professional or recreational, is important for all people because exercises and every sporting activity are predictors of healthy and long life (Torbarina 2011), and since physical activities activate a complete locomotor system crucial to a transformation of energy which is much needed for the activity of all cells in the body, sports and physical activities can be treated as a determinant for a harmonious development of all child's characteristics and anthropological characteristics (Krželj 2009). Physical activity affects the quality of life (Pucci, Rech, Fermino \& Reis 2012). Childhood and youth are the most important formative periods, and some segments of development, for example, specific motor skills can be developed only with means used in sports (Doupona \& Petrovič 1997), so it is important that a selected sporting activity is not burdensome, the one which will make them feel pleasure and joy (Martinčević 2010), and the one which will, at the same time, relieve stress and, above all, create from young age a habit of doing sports which will continue during growing up and become part of everyday life (Krželj 2009). The fact is that a large number of children are involved in organized sports programs, but, entering into puberty, it is evident that most of them quit those programs (Fraser-Thomas, Côté \& Deakin 2008; Horga 2009). Adolescence is a formative period for adopting behaviors relevant to attitudes, habits and lifestyles (Lacković-Grgin 2006). In youth, under the influence of hormones, the appearance of the body changes in girls (the high activity of lipoprotein lipase during puberty causes fat storage and problems with losing it) fat tissue is accumulated under the skin, the body becomes rounded, more feminine and they take on the characteristics of adult women), so a physical growth ends at the end of puberty, and weight gain can continue and is not in proportion to height (Prebeg \& Prebeg 1985). Today, discontent with appearance, especially in girls, is considered a frequent occurrence, most notably in adolescent girls ((Đurović, Mohorić i Pokrajac-Bulian 2007). Physical activity plays an important role in the satisfaction of individuals' lives (Melin, Fugl-Meyer \& Fugl-Meyer 2003), and one of the valuable means of increasing life satisfaction is physical activity (Maher, Pincus, Ram \& Conroyd 2015). Physiological, anatomical, psychological and socio-cultural specifics of 
the female sex require special consideration in all spheres of their physical activities (Greydanaus \& Patel 2002). The term fitness is used in the process of development, raising or maintenance at the optimal level of general psychophysical abilities and characteristics of a body, and it implies a thorough preparation of bodies for efforts and goals of people who are engaged in physical activities for recreational reasons (Omrčen, Andrijašević \& Štefić 2007).

It has been established that aerobic programs have a transformational effect on morphological and motor status, running and walking programs on changes in functional abilities (Sekulić, Rausavljević \& Zenić 2003), while weight exercises have invaluable benefits for the development and maintenance of bone mass of women at all ages (Hagen 2005). The American College of Sports Medicine (ACSM 2010) recommends a cumulative of $20-60$ minutes of moderate aerobic activity 3-5 times per week and resistance training 2-3 times a week by varying the general type of exercise to include muscular strength, muscular endurance, aerobic endurance, anaerobic endurance, flexibility, and mobility. According to the World Health Organization (Global recomendations on Physical activity for health,WHO 2010), physical activity in adults involves leisure activities, transportation (walking or cycling), work activities, housekeeping, games, sports, organized and individual exercise, and all activities that take place within a family, school and sports community.

In order to find ways to include young girls in sports activities, a fitness program aimed at improving strength was implemented in order to determine its effects after eight weeks on the fitness of subjects by comparing changes in their body composition and mobility and stability (FMS method) whose changes in a positive sense are indicators of health what can be a guideline in choosing activities that can be part of a fitness program of this population.

\section{Methods}

The study was conducted on a sample of 22 female subjects of young age (16 years \pm 6 months), of which a control group consisted of 11 female subjects and experimental group were 11 female responders. Prior to the implementation of the program, respondents were not included in any sports-recreational activities and were of optimal health without injuries to the locomotor apparatus. The program was conducted over eight weeks and was focused on improving muscular endurance and fitness. The ACSM (2010) recommends 3 sets of 8-12 repetitions of strength training exercises, two to three times a week. The time, or duration, of a cardiovascular workout 
should be at least 20 - 30 minutes of continuous, rhythmic exercise of large muscle groups. "Time" for a strength-training workout is best quantified in repetitions and sets. The type of training, broken into large categories, includes muscular strength, muscular endurance, aerobic endurance, anaerobic endurance, flexibility, and mobility. The type of training should vary daily throughout a training week. Many athletes find heart-rate training beneficial to ensure proper intensity. The ACSM (2010) recommends an intensity of $65 \%$ - $90 \%$ maximum heart rate (HRmax) during aerobic exercise. The ACSM (2010) recommends an intensity of $50 \%$ to $85 \%$ of HRR for aerobic exercise. This program has been developed by an Exercise Physiologist for those who have a basic level of fitness (that is, they are able to walk comfortably for 30 minutes) (more details at https://getontrackchallenge.com.au/assets/exercise-phys-guides/beginner_final_lowres.pdf). The training is designed to last 45 minutes. It is designed to use your own body weight (table 1). The effects of the program on the fitness condition of the subjects were determined by assessing the body composition parameters (data obtained using the Body composition analyser TANITA BC418) - the total percentage of fat tissue (FAT), the percentage of fat tissue segmentally (percentage of fat tissue of the left leg (FATll), right leg (FATrl), left arm (FATla), right arm (FATra) and body (FATb)) and estimation of mobility and stability levels - based on the application of Functional movement screening (FMS) method (seven tests) before and after the program is implemented.

The statistical program SPSS 16,0 and the following statistical methods were used to obtain valid results: the basic descriptive statistics, the KS test-analysis of the normality of results, the independent t-test - analysis of differences between groups and the dependent t-test-analysis of differences within a group.

Table 1

Fitness program

\begin{tabular}{|c|c|c|c|c|c|c|c|c|c|c|c|c|c|c|}
\hline \multirow{2}{*}{\multicolumn{2}{|c|}{ exercises }} & \multirow{2}{*}{$\begin{array}{l}\text { Week } \rightarrow \\
\text { Session } \rightarrow \\
\end{array}$} & \multicolumn{3}{|l|}{1} & \multicolumn{3}{|l|}{2} & \multicolumn{3}{|l|}{3} & \multicolumn{3}{|l|}{4} \\
\hline & & & 1 & 2 & 3 & 1 & 2 & 3 & 1 & 1 & 2 & 3 & 2 & 3 \\
\hline \multirow[t]{4}{*}{ flexibility } & Calf stretch & $15 \mathrm{sec}$ hold per leg & & & & & & & & & & & & \\
\hline & Lying hamstring stretch & $15 \mathrm{sec}$ hold per leg & & & & & & & & & & & & \\
\hline & Lying hip flexor stretch & 15 sec hold per side & & & & & & & & & & & & \\
\hline & Lying glute-medius stretch & 15 sec hold per side & & & & & & & & & & & & \\
\hline cardio & walking & 5 mins & & & & & & & & & & & & \\
\hline \multirow[t]{3}{*}{ resistance } & $\begin{array}{l}\text { Sit to stand no weights OR } \\
\text { with } 2 \mathrm{~kg} \text { weight }\end{array}$ & \multirow{3}{*}{$\begin{array}{l}\text { Week } 1=10 \text { reps } \\
\text { Week } 3=15 \text { reps } \\
\text { Week } 5=20 \text { reps } \\
\text { Week } 7=25 \text { reps } \\
\text { Hold up to } 1 \text { min }\end{array}$} & & & & & & & & & & & & \\
\hline & Bench push-ups & & & & & & & & & & & & & \\
\hline & Wall plank & & & & & & & & & & & & & \\
\hline
\end{tabular}




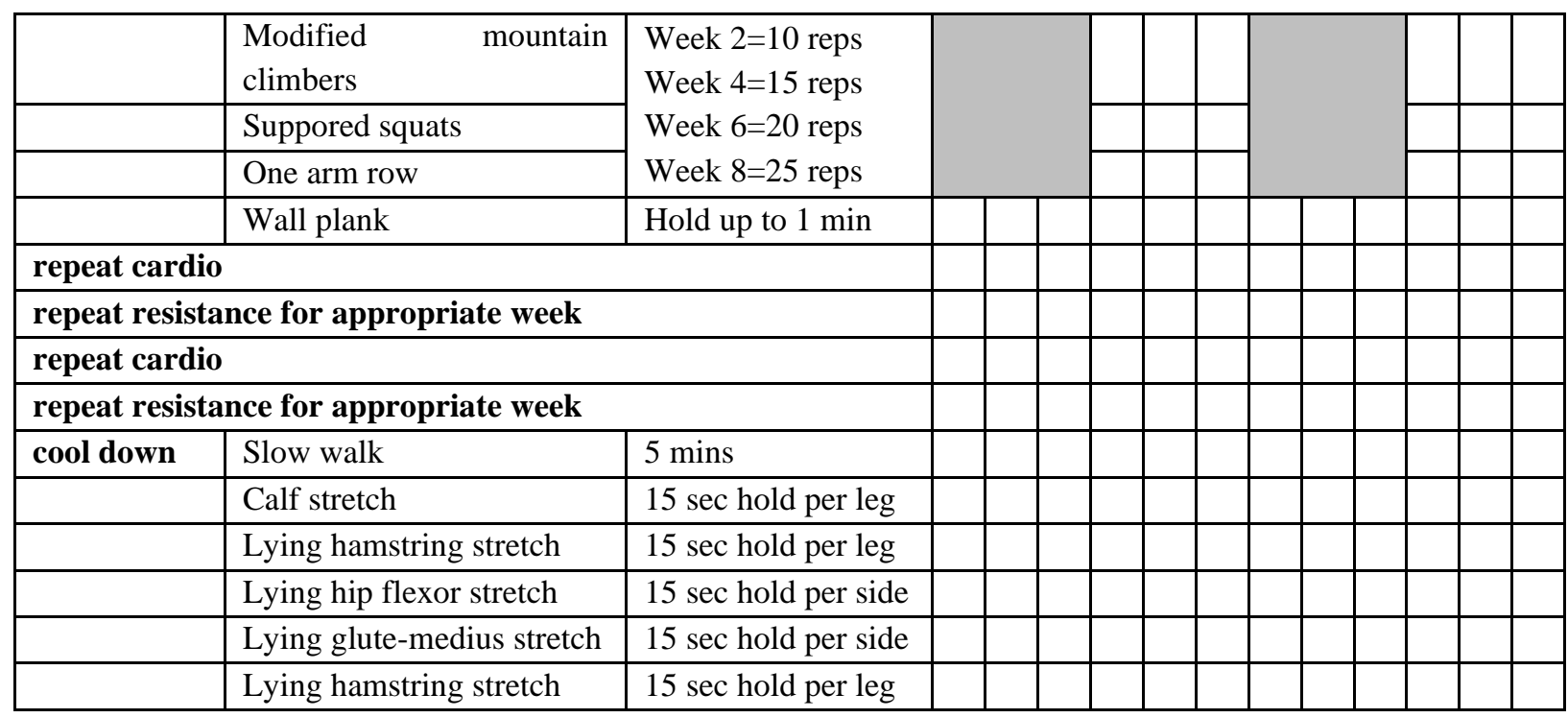

\begin{tabular}{|c|c|c|c|c|c|c|c|c|c|c|c|c|c|c|}
\hline \multirow{2}{*}{\multicolumn{2}{|c|}{ exercises }} & \multirow{2}{*}{$\begin{array}{l}\text { Week } \rightarrow \\
\text { Session } \rightarrow\end{array}$} & \multicolumn{3}{|l|}{5} & \multicolumn{3}{|l|}{6} & \multicolumn{3}{|l|}{7} & \multicolumn{3}{|l|}{8} \\
\hline & & & \multirow[t]{2}{*}{$\mathbf{1}$} & \multirow[t]{2}{*}{2} & 3 & \multirow[t]{2}{*}{1} & \multirow[t]{2}{*}{2} & \multirow[t]{2}{*}{3} & \multirow[t]{2}{*}{1} & \multirow[t]{2}{*}{2} & \multirow[t]{2}{*}{3} & \multirow[t]{2}{*}{1} & \multirow[t]{2}{*}{2} & \multirow[t]{2}{*}{3} \\
\hline flexibility & Calf stretch & $15 \mathrm{sec}$ hold per leg & & & & & & & & & & & & \\
\hline & Lying hamstring stretch & $15 \mathrm{sec}$ hold per leg & & & & & & & & & & & & \\
\hline & Lying hip flexor stretch & 15 sec hold per side & & & & & & & & & & & & \\
\hline & Lying glute-medius stretch & $15 \mathrm{sec}$ hold per side & & & & & & & & & & & & \\
\hline cardio & walking & 5 mins & & & & & & & & & & & & \\
\hline \multirow[t]{7}{*}{ resistance } & $\begin{array}{l}\text { Sit to stand no weights OR } \\
\text { with } 2 \mathrm{~kg} \text { weight }\end{array}$ & \multirow{2}{*}{$\begin{array}{l}\text { Week } 1=10 \text { reps } \\
\text { Week } 3=15 \text { reps } \\
\text { Week } 5=20 \text { reps } \\
\text { Week } 7=25 \text { reps }\end{array}$} & & & & & & & & & & & & \\
\hline & Bench push-ups & & & & & & & & & & & & & \\
\hline & Wall plank & Hold up to $1 \mathrm{~min}$ & & & & & & & & & & & & \\
\hline & $\begin{array}{ll}\text { Modified } & \text { mountain } \\
\text { climbers }\end{array}$ & \multirow{3}{*}{$\begin{array}{l}\text { Week } 2=10 \text { reps } \\
\text { Week } 4=15 \text { reps } \\
\text { Week } 6=20 \text { reps } \\
\text { Week } 8=25 \text { reps }\end{array}$} & & & & & & & & & & & & \\
\hline & Suppored squats & & & & & & & & & & & & & \\
\hline & One arm row & & & & & & & & & & & & & \\
\hline & Wall plank & Hold up to $1 \mathrm{~min}$ & & & & & & & & & & & & \\
\hline \multicolumn{3}{|c|}{ repeat cardio } & & & & & & & & & & & & \\
\hline \multicolumn{3}{|c|}{ repeat resistance for appropriate week } & & & & & & & & & & & & \\
\hline \multicolumn{3}{|c|}{ repeat cardio } & & & & & & & & & & & & \\
\hline \multicolumn{3}{|c|}{ repeat resistance for appropriate week } & & & & & & & & & & & & \\
\hline \multirow[t]{6}{*}{ cool down } & Slow walk & 5 mins & & & & & & & & & & & & \\
\hline & Calf stretch & $15 \mathrm{sec}$ hold per leg & & & & & & & & & & & & \\
\hline & Lying hamstring stretch & $15 \mathrm{sec}$ hold per leg & & & & & & & & & & & & \\
\hline & Lying hip flexor stretch & 15 sec hold per side & & & & & & & & & & & & \\
\hline & Lying glute-medius stretch & 15 sec hold per side & & & & & & & & & & & & \\
\hline & Lying hamstring stretch & $15 \mathrm{sec}$ hold per leg & & & & & & & & & & & & \\
\hline
\end{tabular}




\section{Results and discussion}

Table 2

Descriptive parameters of body composition segmentally at initial and final measurements for both groups of subjects

\begin{tabular}{|c|c|c|c|c|c|c|}
\hline \multicolumn{3}{|l|}{ groups } & $\mathrm{N}$ & $\mathrm{M}$ & S. D & Ks test \\
\hline \multirow{12}{*}{ experimental } & \multirow{6}{*}{ initially } & FATrl & 11 & 36,9545 & 6,13178 & 0,741 \\
\hline & & FATll & 11 & 36,1727 & 6,75812 & 0,711 \\
\hline & & FATra & 11 & 31,7636 & 8,53642 & 0,990 \\
\hline & & FATla & 11 & 32,6455 & 8,72667 & 0,995 \\
\hline & & FATb & 11 & 29,9727 & 9,54307 & 0,977 \\
\hline & & FAT\% & 11 & 23,5210 & 4,8700 & 0,852 \\
\hline & \multirow{6}{*}{ final } & FATrl & 11 & 33,9100 & 6,17368 & 0,857 \\
\hline & & FATll & 11 & 33,9300 & 5,56398 & 0,691 \\
\hline & & FATra & 11 & 28,4700 & 6,34106 & 0,932 \\
\hline & & FATla & 11 & 28,6900 & 6,86399 & 0,657 \\
\hline & & FATb & 11 & 29,4909 & 9,13252 & 0,992 \\
\hline & & FAT\% & 11 & 21,7840 & 5,8700 & 0,852 \\
\hline \multirow{12}{*}{ control } & \multirow{6}{*}{ initially } & FATrl & 11 & 34,7500 & 5,85591 & 0,857 \\
\hline & & FATll & 11 & 34,4000 & 5,35828 & 0,627 \\
\hline & & FATra & 11 & 28,9000 & 6,31489 & 0,954 \\
\hline & & FATla & 11 & 29,1500 & 6,83963 & 0,741 \\
\hline & & FATb & 11 & 36,5000 & 9,74394 & 0,905 \\
\hline & & FAT\% & 11 & 23,7210 & 3,8700 & 0,852 \\
\hline & \multirow{6}{*}{ final } & FATrl & 11 & 36,5545 & 5,69304 & 0,963 \\
\hline & & FATll & 11 & 35,6182 & 6,28567 & 0,887 \\
\hline & & FATra & 11 & 32,7818 & 8,12672 & 0,996 \\
\hline & & FATla & 11 & 32,2636 & 8,79276 & 0,983 \\
\hline & & FATb & 11 & 33,5000 & 7,13754 & 0,634 \\
\hline & & FAT\% & 11 & 23,2210 & 5,8700 & 0,852 \\
\hline
\end{tabular}

From the values shown in Table 2 it can be seen that there was a change in the average values at both groups of subjects - in the experimental group there was a decrease in all the fat tissue values segmentally, and in the control group there was an increase in all fat tissue values, except for body fat tissue.

Table 3

Descriptive test parameters for assessing mobility and body stability-FMS method

\begin{tabular}{|l|l|l|l|l|l|l|}
\hline \multicolumn{2}{|l|}{ groups } & $\mathrm{N}$ & $\mathrm{M}$ & $\mathrm{S} . \mathrm{D}$ & Ks test \\
\hline \multirow{2}{*}{ experimental } & \multirow{2}{*}{ initially } & deep squat & 11 & 1,5455 &, 52223 & 0,548 \\
\cline { 3 - 7 } & hurdle step & 11 & 1,5455 &, 52223 & 0,704 \\
\hline
\end{tabular}




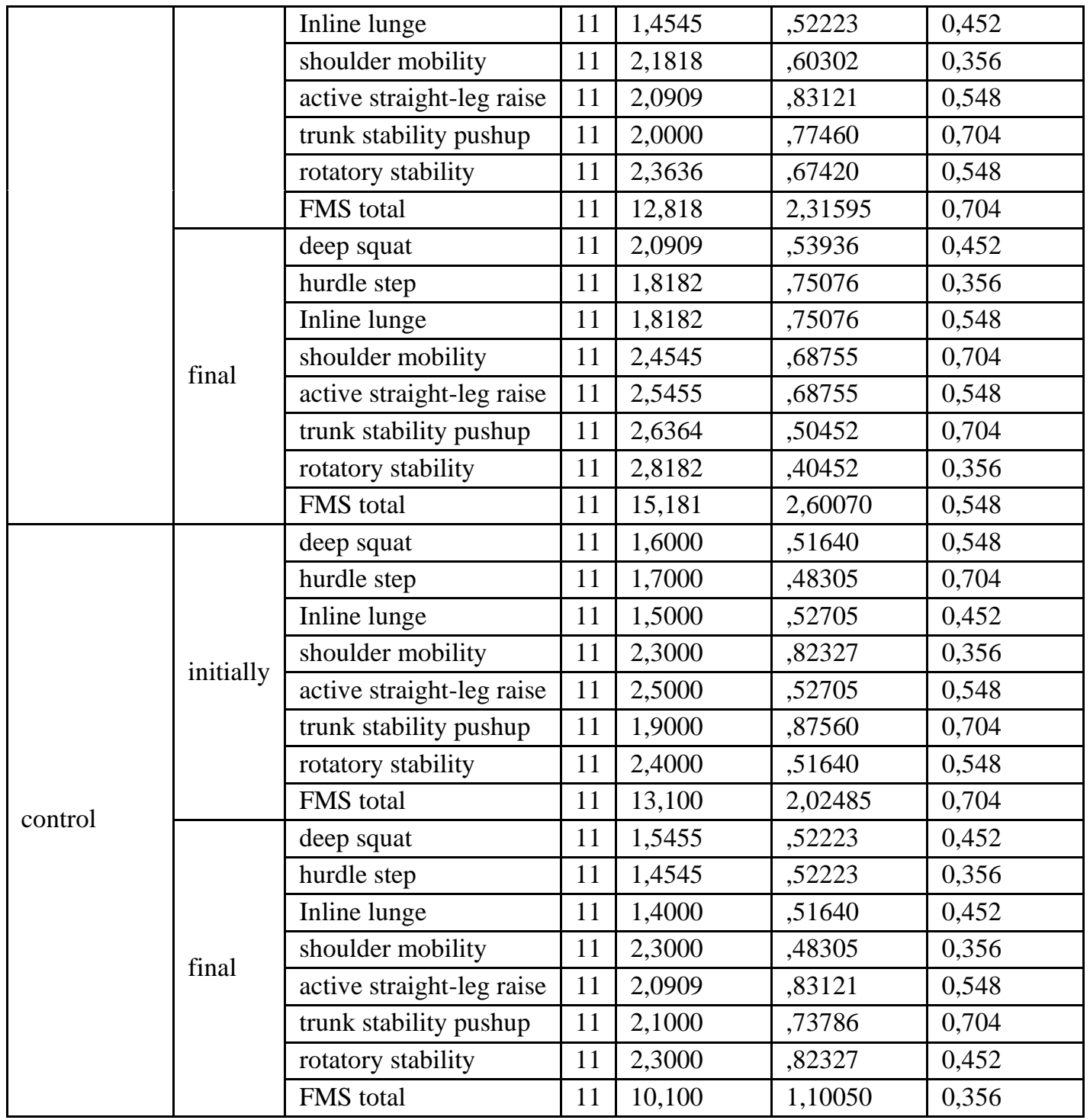

Table 3 shows the values of descriptive statistics of the mobility variables and body stability the FMS method at the initial and final measurement for both groups of subjects. It can be seen from the values shown in Table 3 that there were changes in the average values for both groups of subjects - in the experimental group there was an increase in the average values of the results of mobility and body stability, and in the control group there was a decrease in the average values of mobility results and body stability.

Table 4 shows the results of the statistical analysis of the T-test for independent samples at the initial measurement. On the basis of significance, it can be concluded that there is no statistically significant difference in the initial measurement between the groups of subjects at the 
results of all tests. This shows that the groups are well selected, and the influence of unwanted factors in the further analysis is excluded.

Table 4

Difference between groups initial measurement of the results of all tests

\begin{tabular}{|l|l|l|}
\hline & \multirow{2}{*}{ t-test } & Sig. \\
\cline { 1 - 2 } & & \\
\hline FATrl & 0,168 & 0,868 \\
\hline FATll & 0,271 & 0,789 \\
\hline FATra & 0,638 & 0,531 \\
\hline FATla & 0,841 & 0,411 \\
\hline FATb & 0,661 & 0,516 \\
\hline FAT\% & 0,796 & 0,445 \\
\hline deep squat & 0,866 & 0,397 \\
\hline hurdle step & 1,014 & 0,323 \\
\hline Inline lunge & 0,825 & 0,420 \\
\hline shoulder mobility & 0,209 & 0,837 \\
\hline active straight-leg raise & 0,780 & 0,445 \\
\hline trunk stability pushup & 1,021 & 0,320 \\
\hline rotatory stability & 0,649 & 0,524 \\
\hline FMS total & $-0,295$ & 0,771 \\
\hline
\end{tabular}

Table 5

Difference between groups final measurement of the results of all tests

\begin{tabular}{|l|l|l|}
\hline & \multirow{2}{*}{ t-test } & Sig. \\
\cline { 1 - 3 } FATrl & $\mathbf{3 , 2 1 8}$ & $\mathbf{0 , 0 0 9}$ \\
\hline FATll & $\mathbf{2 , 4 9 8}$ & $\mathbf{0 , 0 3 2}$ \\
\hline FATra & 0,721 & 0,479 \\
\hline FATla & 1,030 & 0,316 \\
\hline FATb & $\mathbf{4 , 0 5 9}$ & $\mathbf{0 , 0 0 2}$ \\
\hline FAT\% & $\mathbf{4 , 6 6 2}$ & $\mathbf{0 , 0 0 1}$ \\
\hline deep squat & $\mathbf{3 , 4 6 4}$ & $\mathbf{0 , 0 0 6}$ \\
\hline hurdle step & $\mathbf{2 , 3 9 0}$ & $\mathbf{0 , 0 3 8}$ \\
\hline Inline lunge & 0,721 & 0,479 \\
\hline shoulder mobility & 1,472 & 0,157 \\
\hline active straight-leg raise & $\mathbf{2 , 8 8 7}$ & $\mathbf{0 , 0 1 6}$ \\
\hline trunk stability pushup & 1,936 & 0,082 \\
\hline rotatory stability & $\mathbf{3 , 1 3 0}$ & $\mathbf{0 , 0 1 1}$ \\
\hline FMS total & $\mathbf{5 , 7 2 1}$ & $\mathbf{0 , 0 0 0}$ \\
\hline
\end{tabular}

Table 5 shows the results of the statistical analysis of the T-test for independent samples at the final measurement. On the basis of significance, it can be concluded that there is no statistically 
significant difference in the final measurement between the groups of subjects at the results of the tests which analyzed the percentage of fat tissue of the upper extremities (FATra and FATla) and in the part of the tests which analyzed the mobility and stability of the body (step forward at the sagittal level, shoulder mobility and push-up stability), while on all other tests (FATrl, FATll, FATb, FAT\%, FMS total - at tests: deep squat, step over a hurdle, active lifting of a stretched leg, rotatory body stability) a significant difference was observed. Based on the average values of the results that the groups of subjects showed at the final measurement, it can be concluded that after the application of the fitness program there was an improvement in the experimental group compared to the control group.

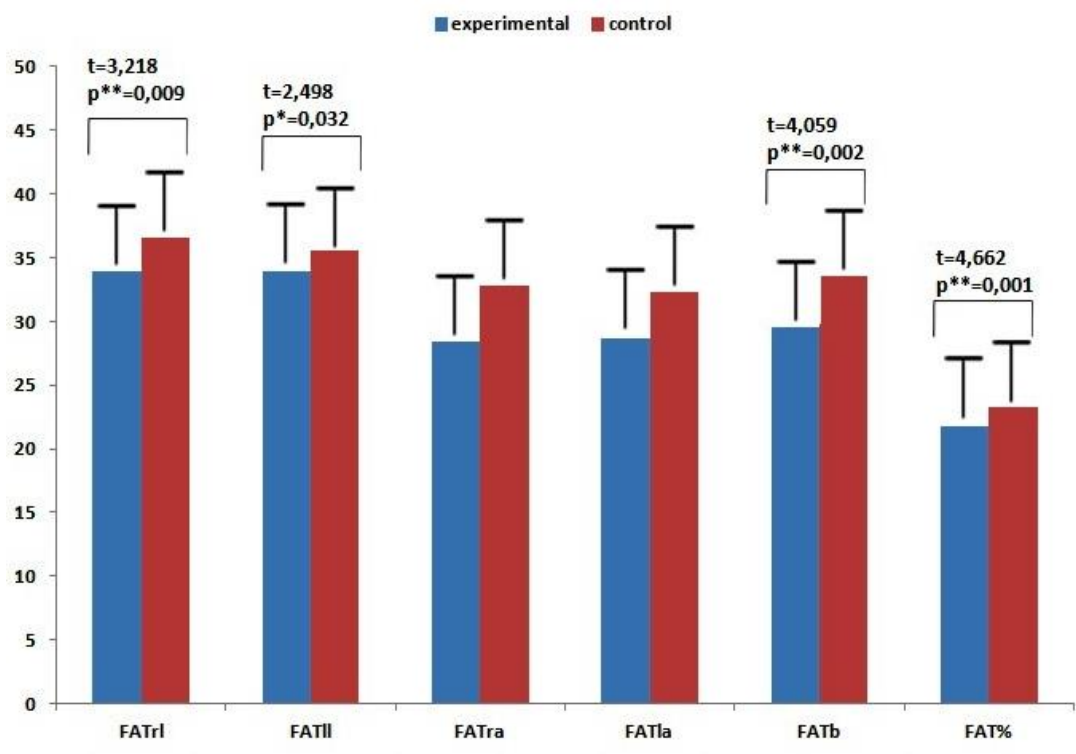

Figure 1

The difference between the results of the experimental and control group at the final measurement regarding variables that measured the body composition segmentally

The success of the implemented program was confirmed because the program showed a statistically significant difference between the mobility groups of the subjects in the experimental in relation to the control group (deep squat $\mathrm{t}=3,464 \mathrm{p}=0,006$, step over a hurdle $\mathrm{t}=2,390 \mathrm{p}=$ 0,038 , active lift of a stretched leg $\mathrm{t}=2,887 \mathrm{p}=0,016$, rotatory body stability $\mathrm{t}=3,130 \mathrm{p}=0,011$ and FMS $\mathrm{t}=5,721 \mathrm{p}=0,000$ ) (Figure 2), and a positive effect on the composition of the body in terms of reduction of the percentage of fatty body has been shown segmentally (FATrl $t=3,218 p$ 
$=0.009$, FATll $\mathrm{t}=2.498 \mathrm{p}=0,032$, FATb $\mathrm{t}=4,059 \mathrm{p}=0,002$ i FAT $\% \mathrm{t}=4,662 \mathrm{p}=0,001$ ) (Figure $1)$.

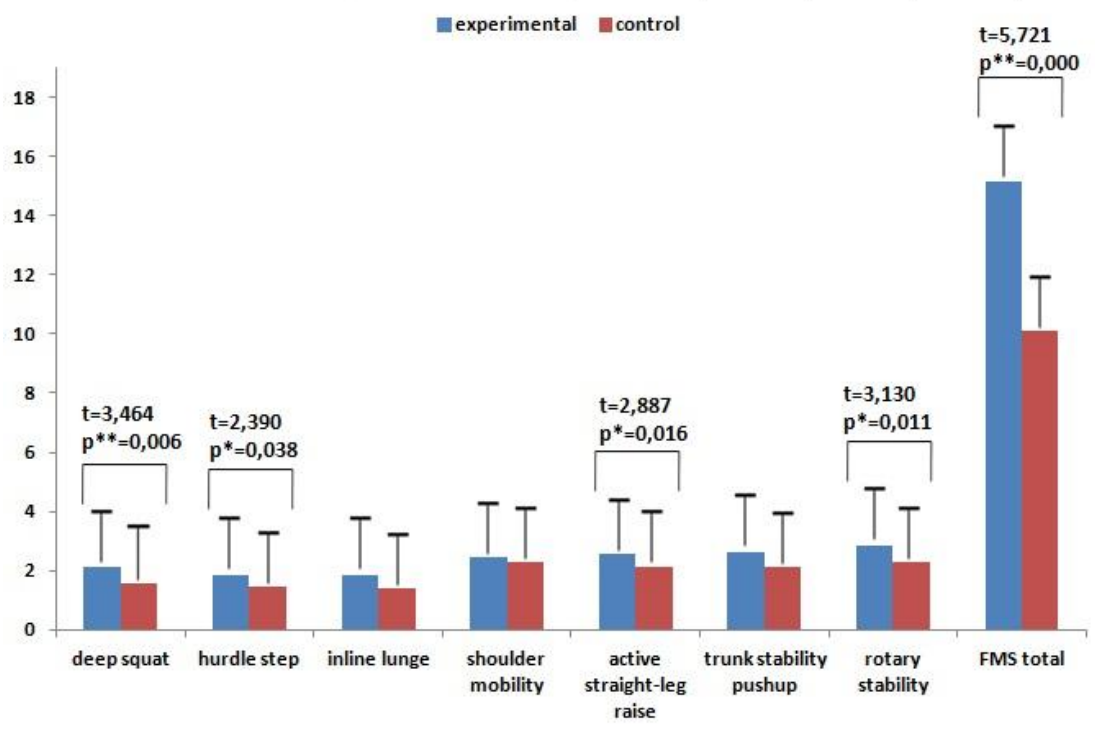

Figure 2

The difference between the results of the experimental and control group at the final measurement regarding the variables that measured stability and mobility

Stojiljković, Mandarić, Todorivić \& Mitić (2010) state that the aerobics program led to significant changes in the morphological and motor skills of female examinees. It also states that programmed systematic exercise influences the transformation of a body composition of women (Fogelholm, Kukkonen-Harjula, \& Oja 1999), and in particular a reduction of body fat percentage in an organism (Širić, Prelčec \& Brčić 2005). It has also been found that in physically active individuals the level of fat oxidation is higher during training (Tremblay, Coveney, Despres, Nadeau \& Prud'homme 1992).

By analyzing the group fitness program it can be noticed that the program was designed for beginners, and that the trainings consisted of several components that affect the morphological and functional characteristics - stretching which improves the mobility of the joints, a cardio part during which the examinees prepared for the main part of the training in which they worked on their strength using the exercise of resistance, and repeated stretching. The characteristic manifestation of the overall morphologically-anatomical, functional and psychological organization of the organism reflects the overall appearance of the human body, giving importance to the overall 
morphological status (Ross, Ward, Leahy \& Day 1982), and in women, a greater percentage of body fat accumulates under the influence of estrogen hormone, which stimulates deposition of fat in the subcutaneous tissue, breast tissue and especially in the gluteal region and thighs. The program has selected exercises for improving mobility and strength improvement training exercises that required an active operation of body muscles and lower extremities. It is known that stretching reduces muscle tension, increases an amplitude of a movement, prevents injuries to muscles and joints, back, stimulates circulation, increases joint mobility, cardio training helps to reduce fat tissue, strengthens the heart muscle and lungs, increases bone density, reduces stress, and that resistance exercises improve muscle strength and increase muscle tone and also increase muscle and fat ratio - when it gets muscles, the body continues to burn fat even at rest. All trainings were moderate to high intensity, and the main feature of high-intensity training is its efficiency in accelerating metabolism and practical application due to time efficiency compared to traditional aerobic exercise (Astorino, Allen, Roberson \& Jurancich 2012). Besides the fact that high intensity training positively influences the reduction of body fat and massless body mass, it also produces positive results on the muscle mass of female subjects (Tremblay, Després, Leblanc, Craig, Ferris, Stephens \& Bouchard 1990; Bryner, Toffle, Ullrich \& Yeater 1997; Sijie, Hainai, Fengying \& Jianxiong 2012; Guiraud, Nigam, Gremeaux, Meyer, Juneau \& Bosquet 2012; Bacon, Carter, Ogle \& Joyner 2013; Smith-Ryan, Trexler, Wingfield \& Blue 2016), which has been shown in this study when it comes to the percentage of fat tissue because the percentage of fatty tissue of body, percentage of trunk fat, and the percentage of lower extremities fat tissue significantly decreased in subjects of the experimental group after the exercise of the fitness program. The body composition of women is characterized by a lower total mass and a smaller percentage of muscle tissue and a larger of fat mass. Women have less ability to generate absolute force, especially in the upper extremities, which is even $50 \%$ lower than men (Kenney, Wilmore \& Costil 2012), which is in line with the results obtained in this study, because although exercises were applied in order to improve the strength of the whole body, the percentage of fat tissue of the upper extremities did not significantly change in the female subjects of the experimental group compared to the subjects of the control group. Reducing fatty tissues of the lower extremities and body can be attributed to the selection of strength exercises because the exercises required the active operation of the muscles of the body and lower extremities. Since it was found that the selected stretching exercises and strength exercises acted positively on muscle activation and reduced fat tissue of the 
body and lower extremities, it was expected that mobility would improve and that a significant difference would be shown among the respondents of the experimental group compared to the subjects of the control group in mobility and stability tests in which muscles of the lower extremities and muscles of the abdomen were more active.

Đug \& Mikić (2007), using the fitness program of step aerobics, both in the anthropometric and motor characteristics of female students, achieved significant partial changes, and Pavić \& Žuvela (2004) found that aerobic exercise led to reduced subcutaneous fat tissue, which confirms that the selection of activities compliant with the goal and age and sex with which it works, results in positive effects. This has also been shown in this research because the selection of a group fitness program, designed by experts and intended for beginners and focused on a comprehensive work of moderate intensity in parts of training dedicated to stretching and cardio programs with a moderately high intensity in improving strength resulted in positive changes in subjects of the adolescent age. As such, it has proven to be a good recreational activity at this age, because it can motivate one to engage further in some group or individual fitness program, because motivation is the main determinant of defining the intensity and depth of involvement in sports and recreational activities.

\section{Conclusion}

Proper understanding of what motivates people to participate will cause effective program planning and implications for health (Snepenger, King, Marshall \& Uysal 2006), because physical activity improves the quality of life for both young and older adults (Joseph, Royse, Benitez \& Pekmezi 2014), and the selection of activities in line with the goal, age and gender which it works with results in positive effects. Adolescence is a period suitable for adopting behaviors relevant to attitudes, habits and lifestyles, because at that age changes in body appearance occur, and girls take on the characteristics of adult women, and physical growth ends at the end of puberty, and weight gain can continue. As more and more girls entering the puberty stops doing sports or recreational activities, it is desirable to motivate them to exercise some kind of physical activity of the type of such a group fitness program for beginners that is aimed at improving strength, since it has been shown that in the youth age of girls this had a positive effect on the reduction of percentage of fatty tissue, but also on increased mobility and stability whose changes in positive sense are indicators of health. All this points to the need to conduct research of a similar nature in order to enable girls 
to engage in sports-recreational activities of a type of group fitness program which do not require too much efforts and which have a positive impact on their health status.

\section{References}

1. ACSM, 2010. ACSM'S Guidelines for Exercise Testing and Prescription. (Senior editor: Thompson, W. R., associate editors: Gordon, N. F., Pescatello), L. S. Philadelphia: American College of Sports Medicine

2. ANONIMUS. beginner_final_lowres.pdf. [Internet] Retrived from https://getontrackchallenge.com.au/assets/exercise-phys-guides/beginner_final_lowres.pdf [14.03.2021.]

3. ASTORINO, T. A., R. P. ALLEN, D. W. ROBERSON \& M. JURANCICH, 2012. Effect of High-Intensity Interval Training on Cardiovascular Function, VO2max, and Muscular Force. The Journal of Strength \& Conditioning Research. 26(1), 138-145.

4. BACON, A. P., R. E. CARTER, E. A. OGLE \& M. J. JOYNER, 2013. VO2max trainability and high intensity interval training in humans: A meta-analysis. PloS one. 8(9), e73182.

5. BRYNER, R. W., R. C. TOFFLE, I. H. ULLRICH \& R. A. YEATER, 1997. The effects of exercise intensity on body composition, weight loss, and dietary composition in women. Journal of the American College of Nutrition. 16(1), 68-73.

6. DOUPONA, M. \& K. PETROVIČ, 1997. Sport kao kakvoća življenja (Slučaj mladih). Kineziologija. 29(1), 21-24.

7. ĐUG, M., \& MIKIĆ, B., 2007. Uticaj step aerobika na transformaciju antropometrijskih karakteristika $i$ motoričkih sposobnosti studenata. Zbornik radova sa III Kongresa i IV Međunarodne naučnekonferencije Crnogorske sportske akademije. (pp. 129-133). Podgorica, MNE.

8. ĐUROVIĆ, D., T. MOHORIĆ \& A. POKRAJAC-BULIN, 2007. Odstupajuće navike hranjenja, nezadovoljstvo tijelom i učestalost provođenja dijete kod hrvatskih srednjoškolaca. Psihološke teme. 16(1), 27-46.

9. FOGELHOLM, M., K. KUKKONEN-HARJULA \& P. OJA, 1999. Eating control and physical activity as determinants of short-term weight maintenance after a very-low-calorie diet among obese women. International Journal of Obesity \& Related Metabolic Disorders, 23(2). 
10. Fraser-Thomas, J., Côté, J., \& Deakin, J. (2008). Examining Adolescent Sport Dropout and Prolonged Engagement from a Developmental Perspective, Journal of Applied Sport Psychology. 20, 318-333.

11. Greydanaus, D., \& Patel, D. (2002). The female athlete before and beyond puberty. Pediatr Clin N Am., 49, 553-580. doi: 10.1016/S0031- 3955(02)00005-6

12. GUIRAUD, T., A. NIGAM, V. GREMEAUX, P. MEYER, M. JUNEAU \& L. BOSQUET, 2012. High-Intensity Interval Training in Cardiac Rehabilitation, Sports medicine. 42(7), 587605.

13. HAGEN, T., 2005. Sports medicine and the adolescent female. J Pediatr Adolesc Gynecol, 18, 9-15. doi: 10.1016/j.jpag.2004.11.005; PMid: 15749579

14. HORGA, S., 2009. Psihologija sporta. Zagreb, RH: Školska knjiga.

15. JOSEPH, R., K. ROYSE, T. BENITEZ \& D. PEKMEZI, 2014. Physical activity and quality of life among university students: exploring self-efficacy, self-esteem, and affect as potential mediators. Quality of Life Research, 659-667.

16. KENNEY, L. W., H. J. WILMORE \& L. D. COSTIL, 2012. Physical Activity for Health and Fitness. In: Physiology of sport and exercise. 5th ed. Champaign. IL: Human Kinetics.

17. KRŽELJ, V., 2009. Dijete i sport. Klinika za dječje bolesti Kliničkog bolničkog centra Split. Split: Medicinski fakultet Sveučilišta u Splitu. Retrived from https://bib.irb.hr/datoteka/513581.Dijete_i_sport.doc

18. LACKOVIĆ-GRGIN, K., 2006. Psihologija adolescencije. Jastrebarsko, RH: Naklada Slap.

19. MAHER, J., A. PINCUS, N. RAM \& D. CONROYD, 2015. Daily Physical Activity and Life Satisfaction across Adulthood. Developmental Psychology. 1407-1419.

20. MARTINČEVIĆ, J., 2010. Provođenje slobodnog vremena i uključenost učenika u izvannastavne aktivnosti unutar škole. Život $i$ škola: časopis za teoriju i praksu odgoja $i$ obrazovanja, 24., 29-34.

21. MELIN, R., K. FUGL-MEYER \& A. FUGL-MEYER, 2003. Life satisfaction in 18- to 64year-old Swedes: in relation to education, employment situation, health and physical activity. Journal of Rehabilitation Medicine, 84-90.

22. OMRČEN, D., M. ANDRIJAŠEVIĆ \& L. ŠTEFIĆ, 2007. Sport, rekreacija i fitnes - analiza odabranih kinezioloških naziva. Društvena istraživanja, 943-964. 
23. PAVIĆ, R. \& F. ŽUVELA, 2004. Uticaj aerobik tretmana na redukciju masnog tkiva žena. In Findak, V. (Eds.), Zbornik radova 13. ljetnje škole kineziolaga Republike Hrvatske. Rovinj, RH: Kineziološki fakultet, Sveučilišta u Zagrebu.

24. PREBEG, Ž. \& Ž. PREBEG, 1985. Higijena $i$ škola. Pedagoška biblioteka.

25. PUCCI, G. C. M. F., C. R. RECH, R. C. FERMINO \& R. S. REIS, 2012. Association between physical activity and quality of life in adults. Rev Saude Publica. 46(1), 1-10.

26. ROSS, W. D., R. WARD, R. M. LEAHY \& J. A. P. DAY, 1982. Proportionality of Montreal athletes. In J.E.L. Carter (Ed.), Physical structure of Olympic athletes: Part 1: The Montreal Olympic Games Anthropometrical Project (pp. 81-106). Basel: Karger.

27. SEKULIĆ, D., N. RAUSAVLJEVIĆ \& N. ZENIĆ, 2003. Changes in motor and morphological measures of young women induced by the HI-LO and STEP aerobic dance programmes. Kinesiology. 35(1), 48-58.

28. SIJIE, T., Y. HAINAI, Y. FENGYING \& W. JIANXIONG, 2012. High intensity interval exercise training in overweight young women. The Journal of Sports Medicine and Physical Fitness. 52(3), 255-262.

29. SMITH-RYAN, A. E., E. T. TREXLER, H. L. WINGFIELD \& M. N. BLUE, 2016. Effects of high-intensity interval training on cardiometabolic risk factors in overweight/obese women. Journal of Sports Sciences. 1-9.

30. SNEPENGER, D., J. KING, E. MARSHALL \& M. UYSAL, 2006. Modeling Iso-Ahola's Motivation Theory in the Tourism Context. Journal of Travel Research. 45(2) 140-149.

31. STOJILJKOVIĆ, S., S. MANDARIĆ, K. TODORIVIĆ \& D. MITIĆ, 2010. Efekti primjene „omnibus “ aerobika na tjelesnu kompoziciju žena. Beograd, RS: Fakultet za sport i fizičko vaspitanje. 796.1-055.2

32. ŠIRIĆ, V., S. PRELČEC \& B. BRČIĆ, 2005. Utjecaj programiranog tjelesnog vježbanja na postotak tjelesne masti, Stručni časopis „Edukacija, rekreacija, sport”. 38 - 42.

33. TORBARINA, Z., 2011. Sport - zaštitni čimbenik u suočavanju s rizničnim ponašanjima djece i mladih. JAHR. 2(3), 65-74.

34. TREMBLAY, A., S. COVENEY, J. P. DESPRES, A. NADEAU \& D. PRUD’HOMME, 1992. Increased resting metabolic rate and lipid oxidation in exercise-trained individuals: evidence for a role of beta-adrenergic 2017. TIMS Acta. 11, 53-64. 
35. TREMBlay, A., J. P. DESPRÉS, C. LEBLANC, C. L. CRAIG, B. FERRIS, T. STEPHENS \& C. BOUCHARD, 1990. Effect of intensity of physical activity on body fatness and fat distribution. The American Journal of Clinical Nutrition. 51(2), 153-157.

36. U.S. DEPARTMENT OF HEALTH AND HUMAN SERVICES, 1996. Physical activity and health: A report of the Surgeon General. Atlanta, GA: U.S. Department of Health and Human Services, Centers for Disease Control and Prevention, National Center for Chronic Disease Prevention and Health Promotion.

37. WHO. World Health Organisation, [Internet] Retrived from http://www.who.int/en/ [12.03.2021.] 